\title{
EDITORIAL
}

\section{Prezados Senhores,}

A Revista AREL FAAR - AMAZON'S RESEARCH AND ENVIRONMENTAL LAW Online é uma publicação quadrimestral do IESUR/FAAr - Instituto de Ensino Superior de Rondônia - que tem por missão disseminar estudos e pesquisas inéditas realizadas na área das Direito, com enfoque voltado para "Sociedade, Empresa e Sustentabilidade" e "Direitos Humanos e suas Dimensões", que são as duas linhas de pesquisa do Núcleo de Pesquisas Científicas em Direito - NUPES/IESUR/FAAr - constituído formalmente, após ser aprovado no CONSEPE da Instituição, em 2012.

É com orgulho que encerramos o exercício de publicações com este número extra do Volume 1 no ano de 2013. Assim, este volume apresenta quatro artigos nacionais seguindo as linhas de pesquisa do NUPES/IESUR/FAAr, selecionados pelo nosso Conselho Editorial como artigos científicos didáticos e de qualidade enviados por advogados e alunos pósgraduação stricto sensu isoladamente ou em coautoria com seu orientador ao longo do ano, como resultado da confiança que os mesmos já possuem em relação ao nosso trabalho.

Também, pela primeira vez, estamos publicando artigos relativos às Jurisprudências do Estado de Rondônia, tanto analisando acórdãos do Tribunal Regional Federal da Primeira Região, quanto do Superior Tribunal de Justiça. Foram duas análises de jurisprudências desenvolvidas, uma em cada Linha de Pesquisa do NUPES/IESUR/FAAr, pelo corpo técnico dos Laboratórios de Humanos e de Sustentabilidade, como forma de comemorar um ano de existência destas unidades de pesquisas sociais aplicadas do IESUR/FAAr, prestigiada Instituição de Ensino Superior situada na microrregião leste de Rondônia.

O número extra do Volume 1 não segue a estrutura das demais edições, uma vez que em cada número editamos sete artigos nacionais, sendo três da categoria Empirical Research Review (seção que visa divulgar a pesquisa empírica no Brasil), sempre com a finalidade de manter uma rígida classificação dos artigos, demonstrada nas edições anteriores.

Aproveitamos a oportunidade para convidar o leitor a enviar seus artigos inéditos e de qualidade. A Revista AREL FAAR recebe artigos: nacionais, internacionais, com análise de jurisprudências e empiricals research review em fluxo contínuo.

As diretrizes para os autores que desejarem contribuir com nossa publicação se encontram no ícone SOBRE da Revista.

A revista possui o International Standart Serial Number (ISSN n 2317-8442) e está 
CLÁUDIA RIBEIRO PEREIRA NUNES E ROSSANA MARINA DE SETA FISCILETTI

indexada no Sistema Eletrônico de Editoração de Revistas (SEER) do Instituto Brasileiro de Informação em Ciência e Tecnologia (IBICT). Indexada, ainda, no portal Diadorim (IBICT).

Cumpre ressaltar que todos os trabalhos submetidos foram analisados por dois avaliadores externos ad hoc, bem como pelo conselho editorial da Revista AREL. Os trabalhos desta publicação tramitaram pelo sistema duble blind peer review.

Agradecemos a todos que contribuíram para o trabalho empreendido e a realização do Volume 1 com a publicação de três números relativos ao ano de 2013.

Resta mencionar o especial agradecimento ao IESUR/FAAr, por todo o apoio da Diretoria, dos Coordenadores Institucionais e do Coordenador de Direito, além do corpo docente e discente, sem os quais esta empreitada de sucesso não poderia ter sido realizada no ano de 2013.

Boa leitura!

\author{
Cláudia Ribeiro Pereira Nunes \\ Editora Chefe \\ Revista AREL \\ e \\ Rossana Marina De Seta Fisciletti \\ Editora Adjunta \\ Revista AREL
}

